\title{
Islam, Gender, dan HAM
}

\author{
Muntoha \\ Universitas Islam Indonesia
}

This paper explains about language function with functionalism approach. In general ethnic group is known as a tribe or community with the same identity or tradition. Identity of the ethnic group includes patterns of kinship, marital, religion, home architecture, settlement, language etc. Language is one of the identity and becomes a collective identity of ethnic. But language can be a nation identity not just an ethnic identity. One of the characteristic of Indonesia is Bahasa Indonesia as a national identity or national language. The mass media like television broadcasting (TVRI and private TV) are the important channels to promote the socialization of using Bahasa Indonesia correctly.

Key words: language, function, integration, identity

$\mathrm{P}$ enistaan terhadap kaum perempuan telah berlangsung lama dalam sejarah peradaban umat manusia, di mana kaum perempuan sering kali dianggap "setengah manusia", "manusia kelas dua", "makhluk pelengkap", "konco wingking", dan lain sebagainya yang hak dan kewajibannya bahkan keberadaannya di dunia ini ditentukan oleh laki-laki sehingga dalam persepektif yuridis, hukum BW (burgelijke wetbook) misalnya, menegaskan bahwa manakala perempuan telah terikat dalam perkawinan yang sah sejak saat itulah perempuan dianggap onbefoegheid (tidak cakap hukum), artinya ia berada di bawah pengampuan suaminya.

Para elite Yunani Kuno menempatkan perempuan sebagai makhluk tahanan yang "disekap" dalam istana. Sementara kalangan bawahannya memperlakukan perempuan sebagai barang dagangan yang diperjualbelikan. Bila sudah menikah, para suami berkuasa penuh terhadap istrinya. Sedangkan Peradaban Romawi menempatkan perempuan sepenuhnya berada di bawah kekuasaan ayahnya. Setelah kawin, kekuasaan pindah ke tangan suami. Kekuasaan ini sangat mutlak, termasuk kewenangan untuk menjual, mengusir, menganiaya, dan membunuh. Fakta pahit tersebut terus berlangsung sampai abad ke-6 Masehi. Masyarakat Hindu pra abad ke-7 Masehi sering menjadikan perempuan sebagai "sesajen" bagi para dewa. Hak hidup perempuan yang bersuami harus berakhir pada saat kematian suaminya; isteri harus dibakar hidup-hidup pada saat mayat suaminya dibakar. Demikian juga dalam tradisi masyarakat Cina terdapat petuah-petuah kuno yang tidak memanusiakan perempuan. Ajaran Yahudi juga menganggap perempuan sebagai sumber laknat karena ia yang menyebabkan Adam terusir dari surga. Ayah berhak menjual anak perempuan kalau ia tidak memiliki anak laki-laki. Dalam tradisi Nasrani pun nasib perempuan sangat menyedihkan. Dalam sebuah konsili yang 
diadakan pada abad ke-5 Masehi dinyatakan bahwa perempuan tidak memiliki ruh yang suci. Pada abad ke-6 sebuah konsili menyimpulkan bahwa perempuan adalah manusia yang diciptakan semata-mata untuk melayani laki-laki. ${ }^{1}$

Pada masa Pra-Islam, dalam tradisi Arab Jahiliyah perempuan dihalalkan untuk dibunuh hanya gara-gara terlahir sebagai bayi perempuan. Pada acara pernikahan, para tamu memberi ucapan kepada mempelai bi al-hanna' wa al-banin (selamat, semoga memperoleh keturunan laki-laki). Setelah menikah, perempuan menjadi hak penuh suami dan keluarganya. Ketika suaminya meninggal, ia tidak bisa menjadi pewaris melainkan benda yang diwariskan. ${ }^{2}$ Artinya, sejarah telah mencatat bahwa sebelum Islam datang posisi wanita hanyalah sebagai obyek, bahkan sering dijadikan komoditas perbudakan dan "seksual". Asumsi yang berkembang saat itu memandang wanita sebagai penghalang kemajuan, terutama di kala peperangan, karenanya lebih baik dikubur hidup-hidup jika ada bayi perempuan. Asumsi ini diluruskan Allah SWT dalam firman-Nya:

"Sesunggunhya laki-laki dan perempuan yang muslim, laki-laki dan perempuan yang mukmin, laki-laki dan perempuan yang tetap dalam ketaatannya, laki-laki dan perempuan yang benar, lakilaki dan perempuan yang sabar, laki-laki dan perempuan yang khusyu', laki-laki dan perempuan yang bersedekah, laki-laki dan perempuan yang berpuasa, laki-laki dan perempuan yang memelihara kehormatannya serta laki-laki dan perempuan yang banyak menyebut asma Allah, Allah telah menyediakan mereka ampunan dan pahala yang besar"3

Sementara di dalam Al-Qur'an sebagai kitab suci yang dipercaya oleh umat Islam dunia merupakan wahyu Allah, di dalamnya banyak ayat Al-Qur'an yang berbicara tentang kekerasan terhadap perempuan. Uslub (gaya bahasa) yang digunakan beragam; ada yang menyuruh berbuat baik terhadap perempuan, ada yang melarang praktik-praktik yang merugikan perempuan; ada yang dikemukakan sebagai langkah preventif untuk melindungi perempuan dari tindak kekerasan, ada pula yang dinyatakan sebagai langkah kuratif terhadap praktik kekerasan yang dialami perempuan, misalnya Q.S. An-Nisa':19, 34 - 35, dan 129; Q.S. Al-Baqarah:232, 228, dan 231; Q.S. Ath-Thalaq:6, dan Q.S. An-Nur:33. Dari ayatayat Al-Qur'an tersebut diketahui banyak persoalan kekerasan terhadap perempuan yang disinggung oleh Al-Qur'an, menyangkut persoalan kekerasan fisik dan seksual, juga menyangkut pemukulan terhadap isteri yang nusyuz, ishlah (rekonsiliasi) sebagai_solusi, larangan mengeksploitasi perempuan untuk menjadi pekerja seks, dan larangan melakukan pelecehan seksual. Menyangkut persoalan kekerasan psikis, Al-Qur'an berbicara tentang larangan melakukan adhal dan memperlakukan perempuan sebagai benda warisan, larangan menyia-nyiakan isteri dan mantan isteri. ${ }^{4}$

Namun, banyaknya ayat Al-Qur'an yang berbicara mengenai kekerasan terhadap perempuan dalam konteks ini menjadi bukti bahwa Islam sangat memberikan perhatian terhadap upaya penghapusan kekerasan terhadap perempuan. Terma perempuan (An-

${ }^{1}$ Quraish Shihab dalam Badriyah Fayumi "Islam dan Masalah Kekerasan Terhadap Perempuan", Tubuh, Seksualitas, dan Kedaulatan Perempuan Bunga Rampai Pemikiran Ulama Muda, Cetakan ke-1, LKiS, Yogyakarta, 2002, hlm. $103-104$.

${ }^{2}$ Fuad Hashem dalam Ibid.

${ }^{3}$ Q. S. Al-Ahzab:35.

${ }^{4}$ Badriyah Fayumi dalam Ibid., hlm. 105- 106. 
Nisa') dalam Al-Qur'an dipergunakan sebanyak 57 kali, sama dengan kata ar-rajul / ar-rijal (laki-laki) ${ }^{5}$ atau al-untsa yang berpasangan dengan al-dzakar, terma ini digunakan oleh Al-Qur'an lebih dari 10 (sepuluh) kali. ${ }^{6}$ Perimbangan ini menurut Said Aqiel Siradj, ${ }^{7}$ selintas memberikan suatu indikasi bahwa antara kedua jenis kelamin tersebut —sungguh pun memiliki perbedaan-diperlakukan dan diperhatikan secara berimbang (sama) oleh Islam. Kesetaraan ini hingga berkali-kali Allah SWT menyebutkan keduanya secara berdampingan dan berpasang-pasangan, seperti dalam ayat ke-40 Surat Ghafir, Ali Imran:195, An-Nahl:97, Al-Ahzab:35 dan lain sebagainya. Bahkan menurutnya, di beberapa hadits, Rasulullah SAW justeru sangat memuliakan dan menghormati wanita daripada laki-laki. Misalnya pada saat baginda Nabi SAW ditanya seorang sahabat perihal "siapa di antara manusia yang paling utama untuk dihormati ?", jawab beliau, "ibumu". Kemudian siapa lagi ?, jawab Nabi ibumu. Kemudian siapa lagi ?, jawab Nabi SAW ibumu. Kemudian siapa lagi ? Jawab Nabi SAW "Bapakmu". ${ }^{8}$ Hadits ini dikuatkan pula dengan sabda beliau, "alJannatu tahta aqdamil ummahat", surga itu di bawah telapak kaki ibu. Oleh karena itu, menurutnya, eksistensi perempuan dalam Islam benar-benar mendapat tempat yang mulia, dia adalah menjadi mitra sejajar lakilaki, tidak seperti dituduhkan oleh sementara masyarakat, bahwa Islam tidak menempatkan perempuan sebagai unsur sub-ordinat dalam pranata sosial. Dengan demikian, kehadiran Islam justeru menlenyapkan diskriminasi pria-wanita.

Persoalan yang muncul kemudian, betapa pun Islam dan DUHAM telah mendasari penyadaran integratif tentang eksistensi perempuan —dalam beberapa hal—sebagai mitra sejajar laki-laki, namun realitas yang terjadi pada saat ini di berbagai negeri yang mayoritas muslim justeru menampilkan pemandangan yang kontradiktif. Pemasungan hak-hak wanita dalam berbagai sektor kehidupan dengan dalih mengaplikasikan ajaran Islam, justeru yang sering didengungkan oleh mereka. Wanita tidak boleh menjadi pemimpin (presiden), tidak boleh menduduki jabatan strategis, haram menuntut hak-hak sosialpolitik dan lain sebagainya. Jelas, ini suatu pen-distorsi-an terhadap ajaran Islam. ${ }^{9}$

Fenomena yang serupa juga terjadi di Indonesia, setidaknya sejak bergulirnya era otonomi daerah hingga akhir Juli 2006 tercatat 56 produk kebijakan daerah dalam berbagai bentuk; Peraturan Daerah (PERDA), qanun, surat edaran, dan Keputusan Kepala Daerah. Dalam pandangan Siti Musdah Mulia, ${ }^{10}$ sebagian Perda tersebut secara struktural dan spesifik mengatur kaum perempuan. Sayangnya, pengaturan terhadap kaum perempuan bukan dalam rangka perlindungan dan pemberdayaan, melainkan lebih dimaksudkan sebagai pengecualian dan pembatasan. Perda-perda tersebut meneguhkan sub-ordinasi perempuan; membatasi hak kebebasan perempuan

\footnotetext{
${ }^{5}$ Lihat: Fuad Abdul Baqi, al-Mu'jam alMufahrash li al-Alfadzil Qur'an al-Karim, Dar el-Fikr, Beirut, 1991, hlm. 871 dan hlm. 384 385.

${ }^{6}$ Ibid., hlm. 118 - 119.

7 Said Aqiel Siradj, Islam Kebangsaan Fiqih Demokratik Kaum Santri, Cetakan ke-1, Fatma Press, Jakarta, 1999, hlm. 17.

${ }^{8}$ HR. Bukhari Muslim.

${ }^{9}$ Said Aqiel Siradj, Op. Cit., hlm. 18.

${ }^{10}$ Siti Musdah Mulia, "Peminggiran Perempuan dalam Perda Syari'at", dalam Tashwirul Afkar, Jurnal Refleksi Pemikiran Keagamaan dan Kebudayaan, Edisi No. 20 Tahun 2006, hlm. $21-22$.
} 
dalam berbusana; membatasi ruang gerak dan mobilitas perempuan; serta membatasi waktu beraktivitas perempuan pada malam hari. Secara eksplisit Perda-perda itu mengekang hak dan kebebasan asasi manusia kaum perempuan; menempatkan perempuan hanya sebagai obyek hukum dan bahkan lebih rendah lagi sebagai obyek seksual. Perda-perda yang mengandung pembatasan terhadap kedaulatan perempuan dan juga berpotensi melahirkan perilaku kekerasan terhadap perempuan, ${ }^{11}$ harus digugat dan direvisi karena menyalahi prinsip-prinsip dasar Negara Indonesia, yakni Pancasila dan UUD 1945. ${ }^{12}$

Selain itu, menurutnya, produk kebijakan tersebut mengingkari nilai-nilai hak asasi manusia (HAM) sebagaimana dijabarkan dalam UU Nomor 7 Tahun 1984 Tentang Pengesahan Konvensi Penghapusan Diskriminasi Terhadap Perempuan, UU Nomor 39 Tahun 1999 Tentang HAM, dan UU Nomor 12 Tahun 2005 Tentang Ratifikasi Kovenan Internasional mengenai Hak-hak Sipil dan Politik. Bahkan, lebih parah lagi Perda-perda tersebut menyimpang dari esensi ajaran Islam yang menempatkan manusia, perempuan dan laki-laki sama-sama sebagai mahluk terhormat dan bermartabat, serta memiliki hak dan kebebasan dasar yang harus dihormati. Pembatasan dan pengekangan terhadap perempuan berarti menegasikan keutuhan kemanusiaan perempuan dan Tuhan pasti "tersinggung" melihat perempuan, makhluk ciptaan-Nya dimarjinalkan. Lalu, benarkah telah terjadi diskriminasi gender terhadap kaum perempuan dalam Perda-perda bernuansa syari'ah di Indonesia?

Sebelum masuk pada pembahasan yang lebih rinci dalam persoalan tersebut di atas, perlu dikemukakan terlebih dahulu mengenai cita negara (staatsidee) hukum dalam sistem konstitusi Negara Indonesia yang mendasari adanya egalitarianisme kedudukan setiap warga negara secara konstitusional.

\section{B. Gender: Implementasi Perlindungan Konstitusional di Indonesia}

Indonesia, sebagai negara yang terlahir pada abad modern melalui Proklamasi 17 Agustus 1945 "mengklaim" dirinya sebagai negara hukum. Hal ini terindikasikan dari adanya suatu ciri negara hukum yang prinsip-prinsipnya dapat dilihat pada Konstitusi Negara R. I. (sebelum dilakukan perubahan), yaitu dalam Pembukaan UUD 1945, Batang Tubuh (non Pasal-pasal tentang HAM), dan Penjelasan UUD 1945 dengan rincian sebagai berikut: ${ }^{13}$

\footnotetext{
${ }^{11}$ Ia memberikan contoh Perda Kota Tangerang Nomor 8 Tahun 2005 Tentang Larangan Pelacuran, yang dalam implementasinya telah menimbulkan kriminalisasi terhadap perempuan yang bekerja di malam hari. Menurutnya, perlakuan ini menyalahi asas "Praduga Tak Bersalah" dalam hokum. Korban pertama dari Perda diskriminatif ini adalah seorang perempuan bernama Lia yang hidup di tengah kemiskinan dan harus berjuang mencari nafkah di malam hari bukanlah suatu kebetulan, melainkan konsekuensi logis dari budaya hukum yang bias gender dan bias nilai-nilai patriarki sehingga memposisikan perempuan sebagai obyek hukum dan pola ini akan terus berulang dan berulang di tempat lain.

${ }^{12}$ la berargumentasi bahwa Amandemen ke-4 UUD 1945, pasal-pasal 28c, 28d, 28h, dan 28i menyebutkan secara jelas hak-hak setiap warga negara, termasuk perempuan untuk mengembangkan diri sebagai manusia bermartabat, hak memperoleh kesempatan yang sama dalam pemerintahan dan hak untuk bebas dari semua bentuk perlakuan diskriminatif.

${ }^{13}$ Dahlan Thaib, Kedaulatan Rakyat, Negara Hukum, dan Konstitusi, Cetakan ke-
} 
1. Pembukaan UUD 1945, memuat dalam alinea pertama kata "perikeadilan", dalam alinea kedua "adil", serta dalam alinea keempat terdapat perkataan "keadilan sosial", dan "kemanusiaan yang adil". Semua istilah itu berindikasi kepada pengertian negara hukum, karena bukankah suatu tujuan hukum itu untuk mencapai negara keadilan. Kemudian dalam Pembukaan UUD 1945 pada alinea keempat juga ditegaskan "maka disusunlah kemerdekaan kebangsaan Indonesia itu dalam suatu Undang-undang Dasar Negara Indonesia";

2. Batang Tubuh UUD 1945, menyatakan bahwa "Presiden Republik Indonesia memegang kekuasaan pemerintahan menurut Undang-undang Dasar" (Pasal 14). Ketentuan ini menunjukkan bahwa presiden dalam menjalankan tugasnya harus mengikuti ketentuan-ketentuan yang sudah ditetapkan dalam Undangundang Dasar. Pasal 9 mengenai sumpah Presiden dan Wakil Presiden "memegang teguh Undang-undang Dasar dan menjalankan segala undangundang dan peraturannya seluruslurusnya". Melarang Presiden dan Wakil Presiden menyimpang dari peraturan perundang-undangan yang berlaku dalam menjalankan tugasnya suatu sumpah yang harus dihormati oleh Presiden dan Wakil Presiden dalam mempertahankan asas negara hukum. Ketentuan ini dipertegas lagi oleh Pasal 27 UUD 1945 yang menetapkan bahwa "segala warga negara bersamaan kedudukannya dalam hukum dan pemerntahan itu dengan tidak ada kecualinya". Pasal ini selain menjamin prinsip equality before the law, suatu hak demokrasi yang fundamental, juga menegaskan kewajiban warga negara untuk menjunjung tinggi hukum suatu prasyarat langgengnya Negara hukum; dan

3. Penjelasan UUD 1945, merupakan penjelasan autentik dan menurut Hukum Tata Negara Indonesia, Penjelasan UUD 1945 itu mempunyai nilai yuridis, dengan huruf besar menyatakan: "Negara Indonesia berdasarkan atas hukum (rechtsstaat) tidak berdasarkan atas kekuasaan belaka (machtsstaat)". Ketentuan yang terakhir ini menjelaskan apa yang tersirat dan tersurat telah dinyatakan dalam Batang Tubuh UUD 1945.

Dari ketiga ketentuan di atas, penegasan secara eksplisit Indonesia sebagai negara hukum dapat dijumpai dalam Penjelasan UUD 1945. Lain halnya dengan dua konstitusi (Konstitusi RIS dan UUDS 1950) yang pernah berlaku di Indonesia, terdapat penegasan secara eksplisit rumusan Indonesia sebagai negara hukum. Dalam Mukaddimah Konstitusi RIS misalnya disebutkan pada alinea ke-4; "untuk mewujudkan kebahagiaan, kesejahteraan, perdamaian, dan kemerdekaan dalam masyarakat dan negara hukum Indonesia merdeka yang berdaulat sempurna". Kemudian di dalam Pasal 1 ayat (1) Konstitusi RIS juga disebutkan; "Republik Indonesia Serikat yang merdeka dan berdaulat ialah suatu negara hukum yang demokrasi dan berbentuk federasi". Demikian pula halnya, di dalam Mukaddimah UUDS 1950 pada alinea keempat menyebutkan:

Maka demi ini kami menyusun kemerdekaan kami itu dalam suatu Piagam

2, Liberty, Yogyakarta, 2000, hlm. 25-26. Lihat juga: Muntoha, "Demokrasi dan Negara Hukum" dalam Jurnal Hukum, FH-UII, Nomor 3 Vol. 16 Juli 2009, hlm. $388-391$. 
Negara yang berbentuk Republik Kesatuan, berdasar pengakuan Ketuhanan Yang Maha Esa, Perikemanusiaan, Kebangsaan, Kerakyatan dan Keadilan Sosial untuk mewujudkan kebahagiaan, kesejahteraan, perdamaian, dan kemerdekaan dalam masyarakat dan negara hukum Indonesia Merdeka yang berdaulat sempurna.

Kemudian di dalam Pasal 1 ayat (1) UUDS 1950 disebutkan; Republik Indonesia yang merdeka dan berdaulat ialah negara hukum yang demokratis dan berbentuk kesatuan. Setelah UUD 1945 dilakukan perubahan, rumusan negara hukum Indonesia yang semula hanya dimuat secara implicit baik di dalam Pembukaan maupun Batang Tubuh UUD 1945 dan secara eksplisit dimuat di dalam Penjelasan UUD 1945, penempatan rumusan negara hukum Indonesia telah bergeser kedalam Batang Tubuh UUD 1945 yang secara tegas dinyatakan di dalam Pasal 1 ayat (3) UUD 1945 yang berbunyi: Negara Indonesia adalah Negara Hukum. Jika dikaitkan dengan unsur-unsur negara hukum sebagaimana yang dikenal dalam teori negara hukum pada umumnya, maka dapat ditemukan pengaturan unsur-unsur negara hukum dalam Batang Tubuh UUD 1945 sebagai berikut:

1. Perlindungan terhadap hak-hak asasi manusia (HAM): ${ }^{14}$

2. Pemisahan / pembagian kekuasaan; ${ }^{15}$

3. Pemerintahan berdasarkan undangundang: ${ }^{16}$ dan

4. Peradilan administrasi yang berdiri sendiri. ${ }^{17}$

Dengan demikian, dalam sistem konstitusi Negara Indonesia cita negara (staatsidee) hukum itu menjadi bagian yang tak terpisahkan dari perkembangan gagasan kenegaraan Indonesia sejak kemerdekaan. Meskipun dalam pasal-pasal UUD 1945 sebelum perubahan, ide negara hukum itu tidak dirumuskan secara eksplisit, tetapi dalam penjelasannya ditegaskan bahwa In-

\begin{abstract}
${ }^{14}$ Perlindungan terhadap HAM di dalam UUD 1945 (sebelum perubahan) selain telah dijamin pengaturannya pada Pembukaan UUD 1945, juga telah diatur dalam Batang Tubuh UUD 1945 yaitu dalam Pasal-pasal 27, 28, 29, 30, 31, dan Pasal 34. Kemudian setelah UUD 1945 dilakukan perubahan, perlindungan terhadap HAM telah dijamin pengaturannya lebih komprehensif lagi jika dibandingkan dengan UUD 1945 sebelum perubahan yang dituangkan dalam pasal-pasal HAM pada bab tersendiri yaitu Bab XA dengan judul "Hak Asasi Manusia", dan di dalamnya terdapat 10 (sepuluh) pasal tentang HAM ditambah 1 (satu) pasal (pasal 28) dari bab sebelumnya (Bab X) tentang "Warga Negara dan Penduduk", sehingga ada 11 (sebelas) pasal tentang HAM mulai dari Pasal 28, 28 A sampai dengan Pasal $28 \mathrm{~J}$.
\end{abstract}

${ }^{15}$ UUD 1945 sebelum perubahan menganut faham pembagian kekuasaan secara vertikal, bukan pemisahan kekuasaan yang bersifat horizontal. Dalam hal ini kedaulatan rakyat dianggap terwujud penuh dalam wadah MPR yang dapat ditafsirkan sebagai lembaga tertinggi ataupun sebagai forum tertinggi. Dari sini, fungsifungsi tertentu dibagikan sebagai tugas dan kewenangan lembaga-lembaga tinggi Negara yang ada di bawahnya, yaitu Presiden, DPR, MA, dan seterusnya. Akan tetapi, dalam Perubahan Pertama dan Kedua UUD 1945, prinsip pemisahan kekuasaan secara horizontal jelas mulai dianut oleh para perumus Perubahan UUD 1945 seperti tercermin dalam Perubahan Pasal 5 ayat (1) dan Pasal 20 ayat (1) sampai ayat (5).

${ }^{16}$ Sebagai suatu negara hukum berdasarkan UUD 1945, Presiden RI memegang kekuasaan pemerintahan menurut UUD, Presiden berhak mengajukan RUU kepada DPR. Presiden menetapkan PP untuk menjalankan UU sebagaimana mestinya. Semua ketentuan UUD 1945 itu merupakan hukum positif yang menjadi dasar konstitusional (Constitutionale atau Grondweteljke Grondslag) dari adanya sifat wetmatigheid van het bestuur, seperti yang telah termuat di dalam Pasal 4 ayat (1) dan Pasal 5 ayat (1) dan (2) UUD 1945.

${ }^{17}$ Meskipun keberadaan peradilan administrasi (administrative court) merupakan ciri khas Negara hokum liberal yang lebih 
donesia menganut ide 'rechtsstaat', bukan 'machtsstaat'. Sementara dalam Konstitusi RIS Tahun 1949, ide negara hukum itu bahkan tegas dicantumkan, demikian pula dalam UUDS 1950, kembali rumusan bahwa Indonesia adalah negara hukum dicantumkan dengan tegas. Bahkan dalam Perubahan Ketiga pada tahun 2001 terhadap UUD Negara R. I. Tahun 1945, ketentuan mengenai negara hukum ini kembali dicantumkan secara tegas dalam Pasal 1 ayat (3) yang berbunyi: "Negara Indonesia adalah Negara Hukum". Oleh karena itu, secara teoritis gagasan kenegaraan Indonesia telah memenuhi persyaratan sebagai negara hukum modern, yaitu negara hukum yang demokratis dan bahkan menganut pula faham negara kesejahteraan (welfare-state).

\section{1) Hak dan Kewajiban Konstitusionalitas Warga Negara}

Sebagai konsekuensi dianutnya cita negara (staatsidee) hukum Indonesia tentu dalam memandang kedudukan setiap warga negara tidak ada perlakuan yang bersifat diskriminatif, melainkan harus memperlakukannya dengan prinsip kesetaraan gender sesuai jaminan perlindungan yang telah menjadi materimuatan dari bebabagi konstitusi yang pernah berlaku di republik ini.

UUD 1945 mengakui dan menghormti hak asasi setiap individu manusia yang berada dalam wilayah Negara Republik Indonesia. Bahkan, penduduk Indonesia apakah berstatus sebagai warga negara Indonesia atau bukan diperlakukan sebagai manusia yang memilki hak dasar yang diakui universal. Prinsip-prinsip HAM itu berlaku pula bagi setiap individu warga negara Indonesia. Di samping jaminan HAM itu, setiap warga negara Indonesia juga diberikan jaminan hak konstitusional dalam UUD 1945 sebagaimana telah diuraikan di atas. Selain itu, terdapat pula ketentuan mengenai jaminan HAM tertentu yang hanya berlaku bagi warga negara atau setidaknya bagi warga negara diberikan kekhususan atau keutamaan-keutamaan tertentu, missal, hak atas pekerjaan, hak atas pendidikan dan lain-lain yang secara timbal balik menimbulkan kewajiban bagi Negara untuk memenuhi hak-hak itu khusus bagi warga negara Indonesia. Artinya, Negara Republik Indonesia tidak wajib memenuhi tuntutan warga negara asing untuk bekerja di Indonesia. Hak-hak tertentu yang dapat dikategorikan sebagai hak konstitusional warga negara adalah sebagai berikut: ${ }^{18}$

mengutamakan perlindungan terhadap hak asasi individu, namun dalam negara hukum Indonesia yang berdasarkan cita Negara (staatsidee) Pancasila peradilan administrasi bukanlah unsur utama, melainkan unsur turunannya yang diturunkan dari unsur utama karena dalam cita Negara (staatsidee) Pancasila lebih mengutamakan masyarakat daripada individu, tetapi tidak berarti bahwa individu tidak mendapatkan tempat sama sekali melainkan harkat dan martabat manusia tetap diperhatikan. Dengan demikian, keberadaan peradilan administrasi Negara di Indonesia merupakan salah satu sarana untuk memberikan perlindungan terhadap hak asasi manusia (HAM) dengan cara melakukan pengawasan atau kontrol judicial terhadap pemerintahan sebagai wujud pengakuan dan perlindungan terhadap hakhak warga negara. Maka, kepada rakyat harus diberi kesempatan untuk menggugat pegawai atau instansi pemerintahan yang melakukan kesalahan dan yang menurut mereka dianggap merugikan hak-hak mereka, sehingga adanya peradilan administrasi diharapkan dapat memberikan jaminan tegaknya keadilan bagi tiap-tiap warga negara.

${ }^{18} \mathrm{Jimly}$ Asshiddiqie, Menuju Negara Hukum Yang Demokratis, Cetakan ke-1, Sekretariat Jenderal dan Kepaniteraan Mahkamah Konstitusi, Jakarta, 2008, hlm. 559 - 561. 
1. HAM tertentu yang hanya berlaku sebagai hak konstitusional bagi warga Negara Indonesia saja. Misalnya; (i) hak yang tercantum dalam Pasal $28 \mathrm{D}$ ayat (3) UUD 1945 yang menyatakan, "Setiap warga negara berhak atas kesempatan yang sama dalam pemerintahan"; (ii) Pasal 27 ayat (2) menyatakan, "Tiap-tiap warga Negara berhak atas pekerjaan dan penghidupan yang layak bagi kemanusiaan"; (iii) Pasal 27 ayat (3) berbunyi, "Setiap warga negara berhak dan wajib ikut serta dalam pembelaan negara"; (iv) Pasal 30 ayat (1) berbunyi, "Tiap-tiap waga negara berhak dan wajib ikut serta dalam usaha pertahanan dan keamanan negara"; (v) Pasal 31 ayat (1) menentukan, "Setiap warga negara berhak mendapat pendidikan". Ketentuan-ketentuan tersebut khusus berlaku bagi warga negara Indonesia, bukan bagi setiap orang yang berada di Indonesia;

2. HAM tertentu yang meski berlaku bagi setiap orang, tetapi dalam kasus-kasus tertentu, khusus bagi warga negara Indonesia, berlaku keutamaankeutamaan tertentu. Misal; (i) Pasal 28 D ayat (2) UUD 1945 menentukan, "Setiap orang berhak untuk bekerja......". Namun, negara dapat membatasi hak orang asing untuk bekerja di Indonesia. Misal, turis asing dilarang memanfaatkan visa kunjungan untuk mendapatkan penghidupan atau imbalan dengan cara bekerja di Indonesia selama masa kunjungannya itu; (ii) Pasal 28 E ayat (3) UUD 1945 menyatakan, "Setiap orang berhak atas kebebasan berserikat, berkumpul, dan mengeluarkan pendapat". Meski ketentuan ini bersifat universal, tetapi dalam implementasinya, orang berkewarganegaraan asing dan warga negara Indonesia tidak mungkin dipersamakan haknya. Orang asing tidak berhak ikut campur dalam urusan dalam negeri Indonesia, misal, secara bebas menyatakan pendapat yang dapat menimbulkan ketegangan sosial tertentu. Demikian pula orang warga negara asing tidak berhak mendirikan partai politik di Indonesia untuk tujuan mempengaruhi kebijakan politik Indonesia; (iii) Pasal $28 \mathrm{H}$ ayat (2) menyatakan, "Setiap orang berhak untuk mendapat kemudahan dan perlakuan khusus untuk memperoleh kesempatan dan manfaat yang sama guna mencapai persamaan dan keadilan". Hal ini juga diutamakan bagi warga negara Indonesia, bukan bagi orang asing yang merupakan tanggung jawab negara asalnya sendiri untuk memberikan perlakuan khusus itu;

3. Hak warga negara untuk menduduki jabatan-jabatan yang diisi melalui prosedur pemilihan (elected officials), seperti presiden dan wakil presiden, gubernur dan wakil gubernur, bupati dan wakil bupati, walikota dan wakil walikota, kepala desa, hakim konstitusi, hakim agung, anggota Badan Pemeriksa Keuangan, anggota lembaga permusyawaratan dan perwakilan yaitu MPR, DPR, DPD dan DPRD, panglima TNI, kepala kepolisian RI, Dewan Gubernur Bank Indonesia, anggota komisi-komisi negara, dan jabatan-jabatan lain yang diisi melalui prosedur pemilihan, baik secara langsung atau secara tidak langsung oleh rakyat;

4. Hak warga negara untuk diangkat dalam jabatan-jabatan tertentu (appointed officials), seperti Tentara Nasional Indonesia, polisi negara, jaksa, pegawai negeri sipil beserta 
jabatan-jabatan struktural dan fungsional dalam lingkungan kepegawaian, dan jabatan-jabatan lain yang diisi melalui pemilihan; dan

5. Hak untuk melakukan upaya hukum dalam melawan atau menggugat keputusan-keputusan negara yang dinilai merugikan hak konstitusional warga negara yang bersangkutan. Upaya hukum dimaksud dapat dilakukan; (i) terhadap keputusan admimnistrasi negara (beschikkingsdad van de administratie), (ii) terhadap ketentuan pengaturan (regelensdaad van staat orgaan), baik materiil maupun formil, dengan cara melakukan substantive judicial review (materiile toetsing) atau procedural judicial review (formele toetsing), atau pun (iii) terhadap putusan hakim (vonnis) dengan cara mengajukannya ke lembaga pengadilan yang lebih tinggi, yaitu tingkat banding, kasasi, atau peninjauan kembali. Misal, Pasal 51 ayat (1) huruf a UU No. 24 Tahun 2003 Tentang Mahkamah Konstitusi menentukan bahwa perorangan warga negara Indonesia dapat menjadi pemohon perkara pengujian undang-undang terhadap undang-undang dasar, yaitu dalam hal yang bersangkutan menganggap bahwa hak (dan / atau kewenangan) konstitusionalnya dirugikan oleh berlakunya sesuatu undang-undang yang dimohonkan pengujiannya.

Selanjutnya sebagai imbangan terhadap adanya jaminan hak konstitusional warga negara tersebut di atas, menurut Jimly Asshiddiqie, ${ }^{19}$ UUD 1945 juga mengatur dan menentukan adanya kewajiban konstitusional setiap warga negara. Serupa dengan hak-hak, kewajiban-kewajiban dimaksud juga terdiri atas (i) kewajiban sebagai manusia atau kewajiban asasi manusia, dan (ii) kewajiban sebagai warga negara. Bahkan, jika dibedakan lagi antara hak dan kewajiban asasi manusia dengan hak dan kewajiban konstitusional warga negara, maka kewajiban-kewajiban dimaksud juga dapat dibedakan antara (i) kewajiban asasi manusia, (ii) kewajiban asasi warga negara, dan (iii) kewajiban konstitusional warga negara. Kewajiban asasi manusia dan kewajiban asasi warga negara yang dimaksud adalah sebagai berikut:

1. Kewajiban setiap orang untuk menghormati HAM orang lain dalam tertib kehidupan bermasyarakat, berbangsa, dan bernegara seperti yang tercantum dalam Pasal $28 \mathrm{~J}$ ayat (1) UUD 1945;

2. Kewajiban setiap orang dalam menjalankan hak dan kebebasannya untuk tunduk kepada pembatasan yang ditetapkan dengan undangundang dengan maksud semata-mata untuk menjamin pengakuan serta penghormatan atas hak dan kebebasan orang lain dan untuk memenuhi tuntutan yang adil sesuai dengan pertimbangan moral, nilai-nilai agama, keamanan, dan ketertiban umum dalam suatu masyarakat demokratis, sebagaimana yang ditentukan dalam Pasal 28J ayat (2) UUD 1945;

3. Kewajiban setiap orang dan setiap warga negara untuk membayar pajak dan pungutan lain yang bersifat memaksa sebagaimana ditentukan dalam Pasal 23 A UUD 1945; dan

4. Kewajiban setiapwarganegarauntukikutserta dalamupayapembelaannegarasebagaimana dimaksud dalam Pasal 27 ayat (3) dan untuk ikut serta dalam usaha pertahanan dan

${ }^{19}$ Jimly Asshiddiqie, Ibid., hlm. 561 - 562. 
keamanan negara sebagaimana dimaksud dalam Pasal 30 ayat (1) UUD 1945.

\section{2) Kesenjangan Implementatif terhadap Pemenuhan Hak-hak Kaum Perempuan}

Dalam rangka mengimplementasikan hak dan kewajiban konstitusionalitas warga negara di atas, apa yang secara konstitusional telah mendapatkan jaminan perlindungan di dalamnya jaminan tersebut juga harus terdapat di dalam peraturan perundang-undangan lainnya (Pasal 29 I ayat [5] UUD 1945). Bahkan, harus pula meratifikasi instrument-instrumen HAM internasional bila dipandang perlu. Maka, selain apa yang sudah dijelaskan di atas Indo- nesia juga memiliki berbagai aturan hukum tentang HAM tersebut. Misalnya, sebelum UUD 1945 dilakukan perubahan ada beberapa UU yang dianggap sebagai pelengkap untuk memenuhi kekurangan pasal-pasal tentang HAM dalam UUD 1945 antara lain; UU No. 14 Tahun 1970, UU No. 8 Tahun 1981, UU No. 39 Tahun 1999, TAP MPR No. XVII / MPR / 1998, dan KEPPRES No. 50 Tahun 1993. Kemudian setelah UUD 1945 dilakukan perubahan lahir satu produk UU yaitu UU No. 26 Tahun 2000. Sedangkan di bidang ratifikasi terhadap instrument-instrumen HAM internasional, Indonesia baru sebagian kecil melakukan ratifikasi terhadap instrument-instrumen HAM internasional tersebut di antaranya adalah sebagai berikut: ${ }^{20}$

\begin{tabular}{|c|c|}
\hline Konvensi & UURatifikasi \\
\hline Konvensi denewa 12 Agustus 1949 & UNo. 59 Tahun 1958 \\
\hline $\begin{array}{l}\text { Konvensi tentang Hak Politik Kaum Perempuan (Convention of Political Rghts } \\
\text { of Women) }\end{array}$ & UNo. 68 Tahun 1958 \\
\hline $\begin{array}{l}\text { Konvensi tentang Penghapusan Segala Bentuk Dskriminasi terhadap } \\
\text { Perempuan (Convention on The Bimination of Discrimination Against Wbmen) }\end{array}$ & UUNb. 7 Tahun 1984 \\
\hline Konvensi Hak Anak (Convention on The Rghts of The Child) & Keppres No. 36 Tahun 1990 \\
\hline $\begin{array}{l}\text { Konvensi Pelarangan, Pengembangan, Poduksi dan Penyimpangan Senjata } \\
\text { Bologis dan Penyimpanannya serta Pemusnahannya (Convention on The } \\
\text { Prohibition of Development, Production and Stocpilling of Becteriological / } \\
\text { Bologicd and Toxic Weapons and on Their Destrudion) }\end{array}$ & Keppres No. 58 Tahun 1991 \\
\hline $\begin{array}{l}\text { Anti Apartheid dalam Oach Paga (International Convention Againts Apartheid in } \\
\text { Sports) }\end{array}$ & WNo. 48 Tahun 1993 \\
\hline $\begin{array}{l}\text { Konvensi Menentang Penyiksaan dan Perlakuan atau Penghukuman Lain yang } \\
\text { Kejam, Tidak Manusiavi, atau Merendahkan Martaba Menusia (Torture } \\
\text { Convention) }\end{array}$ & UNb 5 Tahun 1998 \\
\hline Konvensi Anti Penyiksaan & UUNb. 5 Tahun 1998 \\
\hline $\begin{array}{l}\text { Konvensi Organisasi Buruh Internasional No. } 87 \text { Tahun } 1998 \text { Tentang } \\
\text { Kebebasan Berserikat dan Perlindungan Hek untuk Berorganisasi - ILO } \\
\text { (Internationa Labour Organisation - Convention Association and Protedion on } \\
\text { The Rights to Organise) }\end{array}$ & UNo. 83 Tahun 1998 \\
\hline $\begin{array}{l}\text { Konvensi Internasional tentang Penghapusan Semua Bentuk Diskriminasi Rasial } \\
\text { (Convention on The Bimination of The Radial Dscrimination) }\end{array}$ & UNo. 29 Tahun 1999 \\
\hline Konvensi Hak Ekonomi dan Sosial Budaya & WNo. 11 Tahun 2005 \\
\hline Konvensi Hak Spil dan Hak Politik & WNo. 12 Tahun 2005 \\
\hline
\end{tabular}

20 Imam Kabul, Paradigma Pembangu-nan Hukum di Indonesia, Cetakan ke-1, Kurnia Kalam, Yogyakarta, 2005, hlm. 100 - 102. Lihat juga: Muntoha, "Institusionalisasi Penegakan HAM di Indonesia", dalam Kontribusi Pemikiran Untuk 50 Tahun Prof. DR. Moh. Mahfud MD., SH., Cetakan ke-1, FH-UII Press dan Pascasarjana FH-UII, Yogyakarta, 2007, hlm. 218 - 219. 
Semua ketentuan-ketentuan di atas, merupakan instrument normatif yang masih membutuhkan instrumen-instrumen lain dalam rangka penegakan hak-hak kewarganegaraan (HAM) yaitu instrumen kelembagaan. Sebagai contoh, dalam tulisan ini disebutkan 1 (satu) kelembagaan saja yaitu Komisi Nasional Hak Asasi Manusia (KOMNAS HAM), yang dibentuk atas rekomendasi dari Lokakarya I HAM yang diselenggarakan oleh Departemen Luar Negeri R. I. dengan sponsor dari Perserikatan Bangsa-bangsa (PBB). Maka, pada tahun 1993 lahirlah satu lembaga yang diberi kewenangan untuk melaksanakan penegakan HAM, yaitu Komisi Nasional Hak Asasi Manusia (KOMNAS HAM) berdasarkan Keputusan Presiden Nomor 50 Tahun 1993 tertanggal 7 Juli 1993. ${ }^{21}$ Wujud dari penegakan HAM yang ditugaskan kepada Komnas HAM adalah "membantu pengembangan kondisi yang kondusif bagi pelaksanaan hak asasi manusia sesuai dengan Pancasila, meningkatkan perlindungan hak asasi manusia guna mendukung terwujudnya pembangunan nasional, yaitu pembangunan manusia seutuhnya dan pembangunan masyarakat seluruhnya". ${ }^{22}$ Kemudian Keppres No. 50 Tahun 1993 tersebut diintegrasikan ke dalam UU No. 39 Tahun 1999 yang dalam Pasal 89 sub (3) menyebutkan bahwa tugas dan wewenang Komnas HAM adalah sebagai berikut:23

1. Pengamatan pelaksanaan HAM dan penyusunan laporan hasil pengamatan tersebut;

2. Penyelidikan dan pemeriksaan terhadap peristiwa yang timbul dalam masyarakat yang berdasarkan sifat atau lingkupnya patut diduga terdapat pelanggaran HAM;

3. Pemanggilan kepada pihak pengadu atau korban maupun pihak yang diadukan untuk dimintai dan didengar keterangannya;

4. Pemanggilan saksi untuk dimintai dan didengar kesaksiannya, dan kepada saksi pengadu dimintai dan menyerahkan bukti yang diperlukan;

5. Peninjauan di tempat kejadian dan tempat lainnya yang dianggap perlu;

6. Pemanggilan terhadap pihak terkait untuk memberikan keterangan secara tertulis atau menyerahkan dokumen yang diperlukan sesuai aslinya dengan persetujuan ketua pengadilan;

7. Pemeriksaan setempat terhadap rumah, pekarangan, bangunan, dan tempat-tempat lainnya yang diduduki atau dimiliki pihak tertentu dengan persetujuan ketua pengadilan; dan

8. Pemberian pendapat berdasarkan persetujuan ketua pengadilan terhadap perkara tertentu yang sedang dalam proses peradilan, bilamana dalam perkara tersebut terdapat pelanggaran HAM dalam masalah publik dan acara pemeriksaan oleh pengadilan yang kemudian pendapat Komnas HAM tersebut wajib diberitahukan oleh hakim kepada para pihak.

${ }^{21}$ Sri Hastuti PS, "Perlindungan HAM dalam Empat Konstitusi di Indonesia", dalam Jurnal Magister Hukum Vol. 1 No. 1, Januari 2005, Magister Ilmu Hukum FH-UII, Yogyakarta, 2005, hlm. 24.

${ }^{22} \mathrm{~A}$. Masyhur Effendi, Perlindungan Dimensi HAM dan Proses Dinamika Penyusunan HAM, Cetakan ke-1, Ghalia Indonesia, Jakarta, 2005, hlm. 133. Secara lebih rinci Pasal 1 ayat (7) UU No. 39 Tahun 1999 Tentang HAM mendefinisikan Komnas HAM sebagai lembaga mandiri yang kedudukannya setingkat dengan lembaga negara lainnya yang berfungsi melaksanakan pengkajian, penelitian, penyuluhan, pemantauan, dan mediasi HAM.

${ }^{23}$ Lihat: UU No 39 Tahun 1999 Tentang HAM (Baca juga: A. Masyhur Effendi, Ibid.) 
Selain itu, dalam melaksanakan fungsi seperti tersebut dalam Pasal 76 UU 39 Tahun 1999, Komnas HAM bertugas dan berwenang melakukan hal-hal sebagai berikut:24

1. Perdamaian kedua belah pihak;

2. Penyelesaian perkara melalui cara konsultasi, negosiasi, mediasi, konsiliasi, dan penilaian ahli;

3. Pemberian saran kepada para pihak untuk menyelesaikan sengketa melalui pengadilan;

4. Menyampaikan rekomendasi atas suatu kasus pelanggaran HAM kepada pemerintah untuk ditindaklanjuti penyelesaiannya; dan

5. Penyampaian rekomendasi atas suatu kasus pelanggaran HAM kepada DPRRI untuk ditindaklanjuti.

Sebagai panduan Komnas HAM dalam menangani kasus-kasus HAM, Komnas HAM telah membuat klasifikasi HAM berdasarkan UU No. 39 Tahun 1999 Tentang HAM sebagai berikut:

1. Hak untuk hidup;

2. Hak berkeluarga dan melanjutkan keturunan;

3. Hak mengembangkan diri;

4. Hak memperoleh keadilan;

5. Hak atas kebebasan pribadi;

6. Hak atas rasa aman;

7. Hak atas kesejahteraan;

8. Hak turut serta dalam pemerintahan;

9. Hak wanita; dan

10. Hak anak.

Pengklasifikasian kasus-kasus HAM di atas, dimaksudkan untuk membedakan antara kasus HAM dan bukan kasus HAM karena dalam kenyataannya, tidak semua kasus yang diadukan ke Komnas HAM merupakan kasus HAM. Oleh karena itu, dalam proses menangani pengaduan kasus-kasus HAM Komnas HAM melakukan penilaian; jika bukan merupakan kasus HAM, Komnas HAM akan melanjutkan dengan memberi rekomendasi untuk diselesaikan melalui lembaga yang ditunjuk dan berwenang untuk menyelesaikannya dan berkas tertutup; kemudian jika kasus itu merupakan kasus HAM, Komnas HAM akan melanjutkan melalui prosedur sebagai berikut: ${ }^{25}$

1. Untuk kasus HAM yang tidak dapat dibuktikan, karenanya Komnas HAM akan menghentikan investigasi dan berkasnya ditutup;

2. Untuk kasus HAM yang belum dapat dibuktikan, Komnas HAM akan menindaklanjuti dengan investigasi penuh, jika perlu juga melalui investigasi tertulis. Jika tidak ada tanggapan dari responden sebanyak 3 (tiga) kali, maka Komnas HAM akan melakukan panggilan. Jika tanggapan diterima responden, Komnas HAM tidak perlu melakukan pemanggilan, dan setelah itu akan dilakukan analisis. Jika analisis telah selesai, Komnas HAM akan melakukan langkah-langkah alternatif. Berkas ditutup, rekomendasi (referrel), dan mediasi; serta

3. Untuk kasus HAM yang dapat dibuktikan kebenaraanya, Komnas HAM akan memberikan rekomendasi (referrel) dan selanjutnya dapat dilakukan upaya mediasi.

Sedangkan di dalam Pasal 19 UU No. 26 Tahun 2000 Tentang Pengadilan HAM pada bagian keempat, penyidikan, ayat (1) menyatakan bahwa penyidikan terhadap pelanggaran HAM berat dilakukan oleh Komnas HAM, ayat (2) Komnas HAM dalam melaksanakan penyidikan sebagaimana dimaksud dalam ayat (1) dapat membentuk tim ad hoc yang terdiri atas Komnas HAM

\footnotetext{
${ }^{24}$ A. Masyhur Effendi, Ibid., hlm. 135-136. ${ }^{25}$ Sri Hastuti PS., Op. Cit., hlm. $24-25$.
} 
dan unsur masyarakat. Sekarang, institusionalisasi perlindungan dan penegakan HAM di Indonesia tidak hanya memunculkan Komnas HAM dan Peradilan HAM ad hoc, tetapi kini terdapat Komnas Perempuan yang mempunyai komitmen terhadap hak asasi kaum perempuan, dan Komisi Perlindungan Anak Indonesia (KPAI) yang mempunyai komitmen terhadap hak asasi anak.

Meskipun instrumen normatif maupun institusi sebagai perangkat utama pemenuhan hak-hak warga negara telah sangat memadai di negeri ini, namun khususnya dalam pemenuhan hak-hak kaum perempuan terlihat masih ada kesenjangan yang cukup signifikan. Sebagai contohtelah disebutkan padabagian pendahuluan dari tulisan ini bahwa pada era otonomi daerah ini terdapat sejumlah peraturan daerah (Perda) yang secara struktural dan spesifik mengatur kaum perempuan, bukan dalam rangkaperlindungandan pemberdayaan, tetapi justeru Perda-perdatersebut semakin meneguhkan subordinasi perempuan, membatasi hak kebebasan perempuan, serta membatasi waktu beraktivitas perempuan pada malam hari. Secara eksplisitPerda-perdatersebut mengekang hak dan kebebasan asasi kaum perempuan, menempatkan perempuan hanya sebagai obyek hokum, dan bahkan lebih rendah lagi sebagai obyek seksual. Dengan mengutip pendapat Siti Musdah Mulia, Perda-perda semacam ini disebutnya sebagai "Perda-perda yang memarjinalkan kaum perempuan". Perdaperda tersebut di antaranya adalah sebagai berikut: ${ }^{26}$

${ }^{26}$ Siti Musdah Mulia, Op. Cit., hlm. 41 - 42. 
UNISIA, Vol. XXXIII No. 73 Juli 2010

\section{Daftar Perda Yang Memarjinalkan Kaum Perempuan}

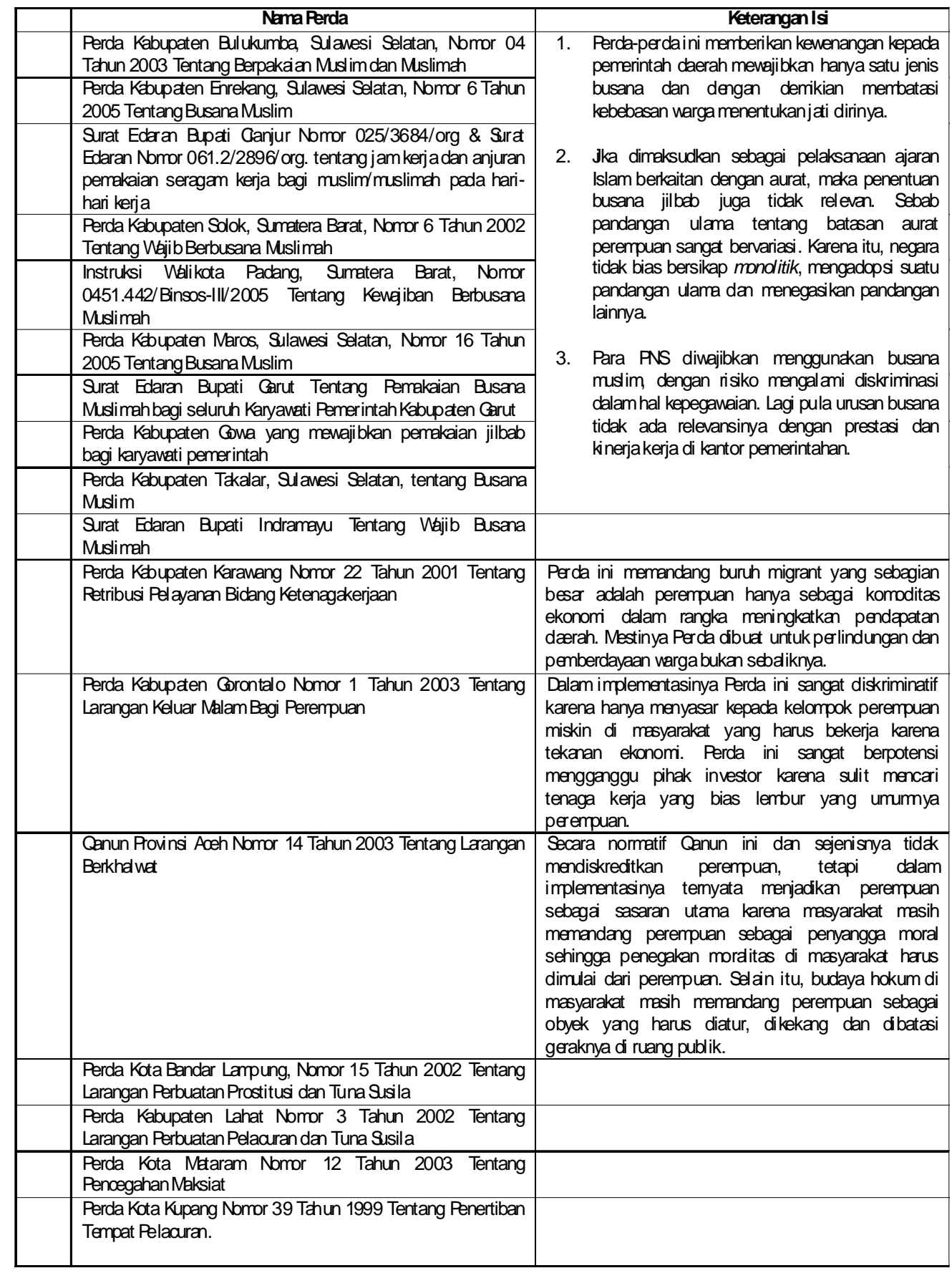


Islam, Gender, dan HAM; Muntoha

Selain ketentuan-ketentuan yang mendiskriminasikan kaum perempuan di atas, juga terdapat tindakan-tindakan yang cenderung mengarah kepada perlakuan diskriminatif terhadap kaum perempuan yang dapat dilihat dari hasil penelitian Pusat Studi Islam (PSI) - Universitas Islam Indonesia (UII) pada tahun 2005 mengenai "Sikap Keagamaan Tentang Keadilan dan Kesetaraan Jender dalam Keluarga di Provinsi Daerah Istimewa Yogyakarta (DIY) sebagai berikut:

\section{i. Melaporkan praktek kekerasan dalam keluarga tetangga kepada pihak yang berwajib}

Sebanyak 2001 responden yang mengisi lengkap untuk indikator melaporkan praktek kekerasan dalam keluarga tetangga kepada pihak yang berwajib, dengan hasil crosstabulation sebagai berikut:
Melaporkan praktek kekerasan dalam keluarga tetangga kepada pihak yang berwajib, menurut sebagian besar responden merupakan tindakan yang baik dan terpuji, yaitu sebesar $69,8 \%$. Sedangkan sebesar $\mathbf{7 , 1 \%}$ responden cenderung bersikap negatif dalam arti buruk dan terhina melaporkan praktek kekerasan dalam keluarga tetangga kepada pihak yang berwajib. Dapat dikatakan bahwa mayoritas responden mempunyai sikap peduli tetangga, dan menolak tindakan kekerasan dalam rumah tangga.

\section{ii. Membeli media yang bergambar porno}

Jumlah responden yang mengisi lengkap untuk indikator membeli media yang bergambar porno sama dengan indikator orang tua mendampingi anak menonton televisi, yaitu sebanyak 1993, dengan hasil crosstabulation sebaaai berikut:

31: Membeli media yang bergambar porno * P32: Membeli media yang bergambar pornc Crosstabulation

\begin{tabular}{|c|c|c|c|c|c|}
\hline & \multicolumn{3}{|c|}{$\begin{array}{l}\text { 32: Membeli media yang bergambar } \\
\text { porno }\end{array}$} & \multirow[b]{2}{*}{ Total } \\
\hline & & Pantas & Netral & Tidak Pantas & \\
\hline \multirow{2}{*}{$\begin{array}{l}\text { P31: Membeli media Pasti } \\
\text { yang bergambar }\end{array}$} & Count & 59 & 9 & 55 & 123 \\
\hline & $\%$ of Total & $3,0 \%$ &, $5 \%$ & $2,8 \%$ & $6,2 \%$ \\
\hline Netral & Count & 7 & 98 & 65 & 170 \\
\hline & $\%$ of Total & ,4\% & $4,9 \%$ & $3,3 \%$ & $8,5 \%$ \\
\hline Tidak Pasti & Count & 36 & 35 & 1629 & 1700 \\
\hline & $\%$ of Total & $1,8 \%$ & $1,8 \%$ & $81,7 \%$ & $85,3 \%$ \\
\hline \multirow[t]{2}{*}{ Total } & Count & 102 & 142 & 1749 & 1993 \\
\hline & $\%$ of Total & $5,1 \%$ & $7,1 \%$ & $87,8 \%$ & $100,0 \%$ \\
\hline
\end{tabular}

Gambar 15. Crosstabulation Sikap Responden Pada Indikator Melaporkan praktek kekerasan dalam keluarga tetangga kepada pihak yang berwajib 
UNISIA, Vol. XXXIII No. 73 Juli 2010

Gambar 18. Crosstabulation Sikap Responden Pada Indikator Membeli media yang bergambar porno

31: Membeli media yang bergambar porno * P32: Membeli media yang bergambar pomc Crosstabulation

\begin{tabular}{|c|c|c|c|c|c|}
\hline & \multicolumn{3}{|c|}{$\begin{array}{l}\text { P32: Membeli media yang bergambar } \\
\text { porno }\end{array}$} & \multirow[b]{2}{*}{ Total } \\
\hline & & Pantas & Netral & Tidak Pantas & \\
\hline \multirow{2}{*}{$\begin{array}{l}\text { P31: Membeli me dia Pasti } \\
\text { yang bergambar }\end{array}$} & Count & 59 & 9 & 55 & 123 \\
\hline & $\%$ of Total & $3,0 \%$ &, $5 \%$ & $2,8 \%$ & $6,2 \%$ \\
\hline \multirow[t]{4}{*}{ porno } & Count & 7 & 98 & 65 & 170 \\
\hline & $\%$ of Total & ,4\% & $4,9 \%$ & $3,3 \%$ & $8,5 \%$ \\
\hline & Count & 36 & 35 & 1629 & 1700 \\
\hline & $\%$ of Total & $1,8 \%$ & $1,8 \%$ & $81,7 \%$ & $85,3 \%$ \\
\hline \multirow[t]{2}{*}{ Total } & Count & 102 & 142 & 1749 & 1993 \\
\hline & $\%$ of Total & $5,1 \%$ & $7,1 \%$ & $87,8 \%$ & $100,0 \%$ \\
\hline
\end{tabular}

Mayoritas responden cenderung bersikap negatif terhadap indikator membeli media yang bergambar porno. Sebanyak $\mathbf{8 1 , 7 \%}$ responden yang menyatakan bahwa disamping tidak pasti membeli media yang bergambar porno juga tidak pantas dilakukan. Ternyata terdapat 59 responden $(3,0 \%)$ responden yang bersikap bahwa membeli media pasti dan pantas. Dari angka ini terlihat bahwa jelas sekali bahwa tindakan kekerasan dalam bentuk membeli media yang bergambar porno adalah tindak yang negatif.

33: Sekelompok masyarakat membakar tempat pelacuran * P34: Sekelompok masyaraka membakar tempat pelacuran Crosstabulation

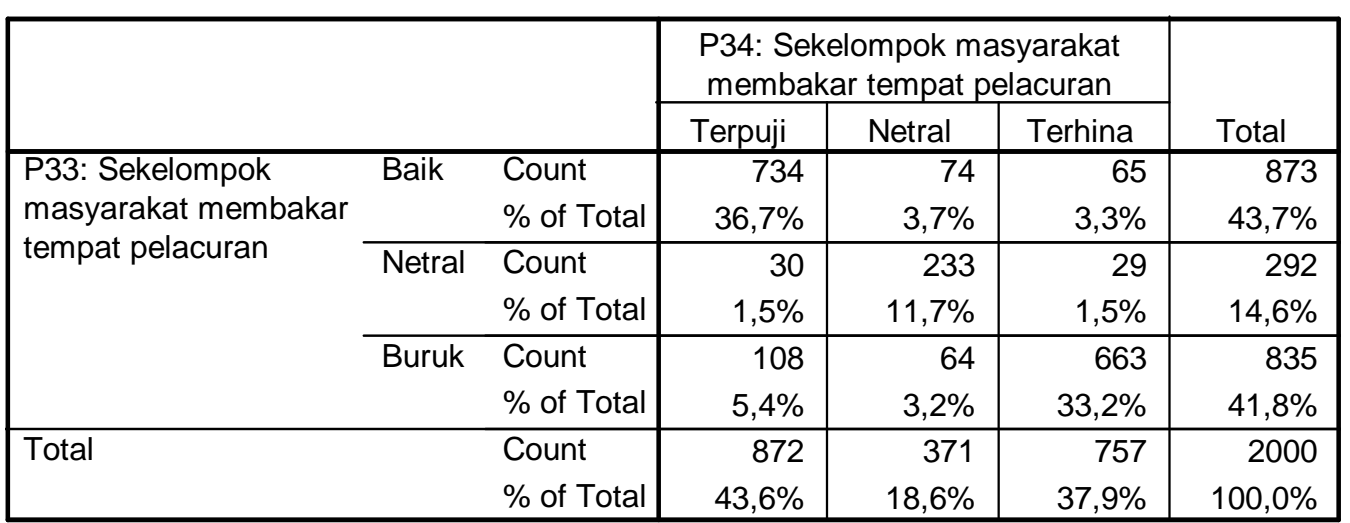

Gambar 19. Crosstabulation Sikap Responden Pada Indikator Sekelompok Masyarakat Membakar Tempat Pelacuran 
Islam, Gender, dan HAM; Muntoha

ii. Sekelompok masyarakat membakar tempat pelacuran

Sebanyak 2000 dari 2007 responden mengisi lengkap untuk indikator sekelompok masyarakat membakar tempat pelacuran, hasil crosstabulation sebagai mana tersebut di Gambar 19.

Dari gambar 19., diperoleh informasi bahwa $\mathbf{3 6 , 7 \%}$ responden bersikap positif yaitu bahwa baik dan terpuji tindakan sekelompok masyarakat yang membakar tempat pelacuran. Sementara $33,2,9 \%$ responden cenderung bersikap bahwa buruk dan terhina tindakan masyarakat yang membakar tempat pelacuran. Perbedaan yang tipis antara kedua sikap ini, menarik untuk diteliti lebih lanjut, khususnya tentang alasan responden yang secara tidak langsung membenarkan adanya tindakan sekelompok masyarakat yang membakar tempat pelacuranm, serta harapan mereka dengan adanya tindakan tersebut.

\section{ii. Bapak/Suami bersikap adil di dalam keluarga}

Jumlah responden yang mengisi lengkap untuk indikator bapak/suami bersikap adil di dalam keluarga sebanyak 1992, dengan hasil crosstabulation sebagai berikut:
Gambar 22. Crosstabulation Sikap Responden Pada Indikator Bapak/ Suami Bersikap Adil Di Dalam Keluarga

Responden yang cenderung bersikap positif terhadap indikator bapak/suami bersikap adil di dalam keluarga sebanyak $90,9 \%$. Jelas bahwa mayoritas responden cenderung menolak tindakan kekerasan dalam bentuk ketidakadilan sikap bapak/ suami di dalam keluarga.

\section{iii. Anggaran publik (APBN/APBD) berpihak terhadap laki-laki dan perempuan}

Kekosongan data terbanyak atau jumlah indikator terbanyak yang tidak diisi responden adalah pada indikator anggaran publik (APBN/APBD) berpihak terhadap lakilaki dan perempuan. Hampir 2,5\% responden tidak mengisi indikator ini, dengan hasil perhitungan sebagai berikut:

Gambar 23. Hasil Perhitungan Pada Indikator Anggaran Publik (APBN/APBD) Berpihak Terhadap Laki-Laki Dan Perempuan

P38: Bapak/Suami bersikap adil di dalam keluarga * P39: Bapak/Suami bersikap adil di dalam keluarga Crosstabulation

\begin{tabular}{|c|c|c|c|c|c|c|}
\hline & & & \multicolumn{3}{|c|}{$\begin{array}{l}\text { P39: Bapak/Suami bersikap adil } \\
\text { dalam keluarga }\end{array}$} & \multirow[b]{2}{*}{ Total } \\
\hline & & & Terpuji & Netral & Terhina & \\
\hline \multirow{6}{*}{$\begin{array}{l}\text { P38: Bapak/Suami } \\
\text { bersikap adil di dalam } \\
\text { keluarga }\end{array}$} & \multirow[t]{2}{*}{ Mantap } & Count & 1810 & 50 & 3 & 1863 \\
\hline & & $\%$ of Total & $90,9 \%$ & $2,5 \%$ & ,2\% & $93,5 \%$ \\
\hline & \multirow[t]{2}{*}{ Netral } & Count & 21 & 89 & 1 & 111 \\
\hline & & $\%$ of Total & $1,1 \%$ & $4,5 \%$ & , 1\% & $5,6 \%$ \\
\hline & \multirow[t]{2}{*}{ Tidak Mantap } & Count & 11 & 2 & 5 & 18 \\
\hline & & $\%$ of Total & ,6\% &, $1 \%$ & ,3\% & ,9\% \\
\hline \multirow[t]{2}{*}{ Total } & & Count & 1842 & 141 & 9 & 1992 \\
\hline & & $\%$ of Total & $92,5 \%$ & $7,1 \%$ &, $5 \%$ & $100,0 \%$ \\
\hline
\end{tabular}


UNISIA, Vol. XXXIII No. 73 Juli 2010

P40: Anggaran publik (APBN/APBD) berpihak terhadap laki-laki dan perempuan

\begin{tabular}{|c|c|c|c|c|c|}
\hline & & Frequency & Percent & Valid Percent & $\begin{array}{c}\text { Cumulative } \\
\text { Percent }\end{array}$ \\
\hline \multirow[t]{4}{*}{ Valid } & Besar & 638 & 31,8 & 32,6 & 32,6 \\
\hline & Netral & 1095 & 54,6 & 56,0 & 88,6 \\
\hline & Kecil & 224 & 11,2 & 11,4 & 100,0 \\
\hline & Total & 1957 & 97,5 & 100,0 & \\
\hline Missing & System & 50 & 2,5 & & \\
\hline Total & & 2007 & 100,0 & & \\
\hline
\end{tabular}

Sebesar $\mathbf{5 4 , 6 \%}$ responden bersikap kurang jelas terhadap indikator anggaran publik (APBN/APBD) berpihak terhadap lakilaki dan perempuan. Apabila dikaitkan dengan paling banyaknya responden yang tidak mengisi indikator ini, menunjukkan bahwa indikator sulit ditangkap maknanya atau membingungkan responden. Sementara responden yang cenderung bersikap positif sebesar $\mathbf{3 1 , 8 \%}$.

Dari data hasil penelitian PSI - UII di atas, menunjukkan betapa signifikannya perlakuan diskriminatif terhadap kaum perempuan yang notabene baru dalam skala local di wilayah Provinsi DIY. Bagaimana jika ditarik kedalam skala nasional tentu akan memperoleh kesimpulan yang sama, karena struktur sosial yang berkembang cenderung memarjinalkan kaum perempuan dan hal ini dilanggengkan oleh struktur masyarakat patriarkis. Padahal dalam uraian di atas telah ditegaskan bahwa hak konstitusional warga negara yang meliputi HAM dan hak warga negara yang telah dijamin dalam UUD 1945 berlaku bagi setiap warga negara Indonesia. Artinya, hak konstitusional itu dimiliki oleh setiap individu warga negara tanpa pembedaan, baik berdasarkan suku, agama, keyakinan politik, atau pun jenis kelamin. Hak-hak tersebut diakui dan dijamin oleh konstitusi untuk setiap warga negara bagi laki-laki maupun perempuan.

Penegasan UUD 1945 sangat jelas bahwa "Setiap orang berhak bebas dari perlakuan yang bersifat diskriminatif atas dasar apa pun dan berhak mendapatkan perlindungan terhadap perlakuan yang bersifat diskriminatif itu". Bahkan, pentingnya menghapuskan diskriminasi terhadap perempuan diupayakan melalui perlakuan khusus untuk memperoleh kesempatan dan manfaat yang sama guna mencapai persamaan dan keadilan juga telah dijamin oleh UUD 1945 dalam Pasal 28 H ayat (2) yang menyatakan "Setiap rang berhak mendapat kemudahan dan perlakuan khusus untuk memperoleh kesempatan dan manfaat yang sama guna mencapai persamaan dan keadilan". Hal ini juga telah diakui secara internasional yang diwujudkan dalam konvensi tersendiri, yaitu Convention on The Elimination of All Forms of Discrimination Againts Women (Cedaw) sebagaimana telah disebutkan dalam daftar table konvensi internasional di atas. ${ }^{27}$

${ }^{27}$ Menurut Jimly Asshiddiqie, penghapusan diskriminasi melalui pemajuan perempuan menuju kesetaraan jender bahkan dirumuskan sebagai kebutuhan dasar 
Pada tingkat nasional telah dilakukan upaya untuk menghapuskan diskriminasi terhadap kaum perempuan dalam mencapai kesetaraan jender dengan telah diratifikasikannya Cedaw sejak tahun 1984 melalui UU Nomor 7 Tahun 1984. Upaya untuk memberikan perlakuan khusus untuk mencapai persamaan jender juga telah dilakukan melalui beberapa peraturan perundang-undangan, baik berupa prinsipprinsip umum, ${ }^{28}$ maupun dengan menentukan kuota tertentu. ${ }^{29}$ Bahkan, untuk memberikan perlindungan terhadap kaum perempuan yang sering menjadi korban kekerasan, telah dibentuk UU Nomor 23 Tahun 2004 Tentang Penghapusan Kekerasan dalam Rumah Tangga.

Dengan demikian, tindakan diskriminatif terhadap kaum perempuan seperti terlihat pada data hasil penelitian PSI - UII di atas merupakan tindakan melanggar HAM dan hak konstitusional warga negara, serta dengan sendirinya bertentangan dengan UUD 1945 termasuk ketentuan-ketentuan Perda serta peraturan lain di atas yang tidak menunjukkan adanya keadilan dan kesetaraan jender.

\section{Penutup}

Dari fenomena di atas, dapat disimpulkan bahwa kesenjangan implementasi terhadap pemenuhan hak konstitusional warga negara yang meliputi HAM dan hak warga Negara khususnya perlakuan diskriminatif terhadap kaum perempuan, harus disikapi dengan perhatian yang sangat serius baik dari aspek aturan (legal substance), struktur (legal structure), maupun budaya (legal culture). Ketiga aspek tersebut merupakan komponen utama dalam upaya penegakan hak konstitusional kaum perempuan sebagaimana telah dijamin dalam UUD 1945. Agar ketentuan-ketentuan konstitusional itu dipatuhi dan dilaksanakan baik oleh pemerintah maupun warga negara, maka dalam penegakannya harus melibatkan semua komponen bangsa, baik lembaga dan pejabat negara serta warga negaranya; laki-laki maupun perempuan sehingga dapat menjamin tegaknya pelaksanaan hak konstitusional kaum perempuan. Selain itu, budaya masyarakat patriarkis di tengah-tengah bangsa ini harus segera dikikis dengan merevitalisasi nilainilai budaya yang merefleksikan pengakuan terhadap hak-hak kaum perempuan, sehingga tidak dijumpai lagi pemarjinalan terhadap kaum perempuan.

pemajuan HAM dalam Millenium Development Goals (MDGs). Hal itu diwujudkan dalam 8 (delapan) area upaya pencapaian MDGs yang di antaranya adalah; mempromosikan kesetaraan jender dan meningkatkan keberdayaan perempuan, dan meningkatkan kesehatan ibu. Rumusan tersebut didasari kenyataan bahwa perempuan mewakili setengah dari jumlah penduduk dunia serta sekitar $70 \%$ penduduk miskin dunia adalah perempuan (Jimly Asshiddiqie, Menuju Negara ... Op. Cit., hlm. 564).

${ }^{28}$ Misal, Pasal 13 ayat (3) UU Nomor 31 Tahun 2002 Tentang Partai Politik menyatakan "Kepengurusan Partai Politik di setiap tingkatan dipilih secara demokratis melalui forum musyawarah partai politik sesuai dengan anggaran dasar dan anggaran rumah tangga dengan memperhatikan kesetaraan dan keadilan jender".

${ }^{29}$ Misal, Pasal 65 UU Nomor 12 Tahun 2003 Tentang Pemilihan Umum Anggota DPR, DPD dan DPRD menyatakan "Setiap Partai Politik Peserta Pemilu dapat mengajukan calon anggota DPR, DPRD Provinsi, dan DPRD Kabupaten / Kota untuk setiap Daerah Pemilihan dengan memperhatikan keterwakilan perempuan sekurang-kurangnya $30 \% "$. 